\title{
GAMBARAN BIONOMIK NYAMUK AEDES AEGYPTI DI KELURAHAN PERUMNAS WAY KANDIS KOTA BANDAR LAMPUNG
}

\author{
Winda Dwi Kusuma ${ }^{1)}$
}

\begin{abstract}
Abstrak
Penyakit Demam Berdarah (DBD) disebabkan oleh virus dengue yang ditularkan melalui gigitan nyamuk Aedes aegypti dan Aedes albopictus. Hasil pemeriksaan jentik di wilayah kerja Puskesmas Way Kandis tahun 2014 dan 2015, diketahui House Index (HI) sebesar 17\% dan 11\%, menunjukkan kepadatan jentik yang tinggi. Penelitian ini bertujuan untuk mengetahui gambaran bionomik nyamuk Ae. aegypti.

Penelitian dilaksanakan di Kelurahan Perumnas Way Kandis pada bulan Juni-Juli 2016. Populasi adalah seluruh rumah sebanyak 1.527 rumah. Sampel dipilih secara acak proporsional, sebanyak 94 . Variabel yang diteliti adalah perilaku mencari tempat perindukan (jenis kontainer, bahan kontainer, letak kontainer, warna kontainer, suhu ruangan, kelembaban udara, intensitas cahaya), dan perilaku nyamuk dalam mencari tempat peristirahatan (letak atau tempal, suhu ruangan, kelembaban udara dan intensitas cahaya).

Hasil penelitian mendapatkan indeks kepadatan jentik secara berurutan $\mathrm{HI}=31,9 \%, \mathrm{CI}=44,4 \%$ dan $\mathrm{BI}=59,6 \%$. Tempat yang paling disukai nyamuk Ae. aegypti untuk berkembang biak adalah kontainer jenis bak mandi/wc, berbahan dasar plastik, berwarna gelap, berada di dalam rumah, suhu ruangan sekitar $29,54^{\circ} \mathrm{C}$, kelembaban udara sekitar $76,29 \%$, dan intensitas cahaya sekitar 46,50 lux. Sedangkan tempat peristirahatan yang paing disukai berada di dalam rumah, suhu ruangan sekitar $29,46^{\circ} \mathrm{C}$, kelembaban udara sekitar $76 \%$, intensitas cahaya sekitar 62,30 lux.

Perlu peningkatan kegiatan pemberantasan sarang nyamuk (PSN) melalui gerakan 3M (MengurasMenutup-Mengubur). Peningkatan pengetahuan dan kesadaran masyarakat dalam pengelolaan lingkungan menjadi perhatian utama dalam keberhasilan program pengendalian penyakit DBD.
\end{abstract}

Kata Kunci: Aedes aegypty, bionomik, perindukan

1) Alumni Prodi D3 Kesehatan Lingkungan Poltekkes Tanjungkarang

\section{PENDAHULUAN}

Penyakit Demam Berdarah Dengue (DBD) adalah penyakit menular yang menyebabkan gangguan pada pembuluh darah kapiler dan sistem pembekuan darah sehingga mengakibatkan perdarahan dan dapat menimbulkan kematian. DBD disebabkan oleh virus dengue yang ditularkan melalui gigitan nyamuk Ae. aegypti dan Aedes albopictus (Zulkoni, 2011; Widoyono, 2008). DBD menjadi salah satu penyakit virus yang berbahaya, karena dapat menimbulkan kematian penderita dalam waktu yang singkat (Safar, 2010).

Penyakit DBD dapat menyerang semua orang dan dapat mengakibatkan kematian, terutama pada anak-anak. Orang yang terinfeksi menderita virus dengue akan menunjukkan gejala demam mendadak selama 2-7 hari tanpa penyebab yang jelas, manifestasi pendarahan, trombocitopeni (jumlah trombosit $\leq$
$100.0000 / \mu \mathrm{L}$, hemokonsentrasi (peningkatan hematokrit $\geq 20 \%$ ) disertai dengan dan tanpa pembesaran hati (hematomegali) (Kemenkes RI, 2005; Hadinegoro, 2002).

Puskesmas Way Kandis berada pada urutan kedua dengan jumlah kasus DBD tertinggi di Kota Bandar Lampung. Jumlah penderita DBD pada tahun 2010 sebanyak 60 kasus (dengán 2 kematian), tahun 2011 sebanyak 31 kasus, tahun 2012 meningkat menjadi 147 kasus, tahun 2013 sebanyak 30 kasus, dan pada tahun 2014 sebanyak 31 kasus. Dari data tersebut menunjukkan bahwa hampir setiap tahun terdapat kasus DBD dengan jumlah yang bervariasi.

Salah satu faktor risiko penularan penyakit DBD kepadatan nyamuk. Menurut Yudhastuti, $\mathrm{R}$ dan Vidiyani, A (2005), ada hubungan yang erat antara kepadatan nyamuk dengan tingginya kasus DBD. Faktor yang mendudkung 
kepadatan jentik adalah kelembaban udara, dan jenis kontainer.

Wilayah kerja Puskesmas Way Kandis terdiri dari 5 Kelurahan yaitu Kelurahan Tanjung Senang, Pematang Wangi, Perumnas Way Kandis, Way Kandis dan Labuhan Dalam. Berdasarkan hasil Pemeriksaan Jentik Berkala (PJB), Angka Bebas Jentik (ABJ) di beberapa kelurahan berada di atas batas tetapan nasional $(\geq 95 \%$ ), salah satunya yaitu pada Kelurahan Perumnas Way Kandis. ABJ Kelurahan Perumnas Way Kandis tahun 2014 dan 2015 sebesar $83 \%$ dan $89 \%$.

Nyamuk Ae aegypti dewasa berukuran lebih kecil dibandingkan jenis nyamuk lainnya, mempunyai dasar hitam dengan bintik-bintik putih pada badan dan kaki, serta mempunyai bentuk lira (lyre-form) berwarna putih pada bagian punggung (mesonatum). Telur Ae. aegypti mempunyai pelana terbuka dan gigi sisir yang berduri lateral (Safar, 2010).

Dalam kehidupannya, Ae. aegypti memiliki perilaku atau kesenangan (bionomik) terutama dalam memilih tempat perindukan dan istirahat. Menurut Sitio, A (2008), bionomik nyamuk terdapat pada stadium pradewasa (telur, jentik, pupa), dan stadium dewasa. Hal ini menyangkut tempat dan waktu nyamuk meletakkan telur (perilaku tempat perindukan), perilaku perkawinan, perilaku menggigit (bitting behaviour), dan perilaku istirahat (resting habit) dari nyamuk dewasa.

Penelitian bertujuan mendapatkan gambaran bionomik nyamuk Ae. aegypti di Kelurahan Perumnas Way Kandis Kota Bandar Lampung.

\section{METODE}

Jenis penelitian ini adalah penelitian deskriptif dengan tujuan untuk mengetahui gambaran bionomik nyamuk Ae, aegypti di Kelurahan Perumnas Way Kandis Kota Bandar Lampung. Penelitian dilaksanakan pada bulan Juni-Juli 2016. Variabel yang diteliti adalah tempat perindukan nyamuk (meliputi jenis kontainer, tempat kontainer, bahan kontainer, warna kontainer, suhu ruangan, kelembaban dan pencahayaan), serta tempat peristirahatan nyamuk (tempat, suhu ruangan, kelembaban dan pencahayaan). Pada penelitian ini juga dihitung indeks kepadatan jentik, yaitu House Index (HI), Container Index (CI), dan Breteau Index (BI).

Populasi dalam penelitian ini adalah seluruh rumah di Kelurahan Perumnas Way Kandis, sebanyak 1.527 rumah. Sampel ditentukan secara proporsional, berdasarkan jumlah populasi di setiap RT. Metode sampel secara acak sistematik sederhana. Jumlah sampel sebanyak 94 rumah tangga, dihitung mengikuti Notoatmodjo (2005).

Data dikumpulkan dengan pengamatan (observasi) dan pengukuran. Pengolahan data menggunakan SPSS, dianalisis secara univariate (frekuensi dan proporsi).

\section{HASIL}

\section{Gambaran Umum Lokasi}

Kelurahan Perumnas Way Kandis terletak di Jalan Pulau Damar, Kecamatan Tanjung Senang, Kota Bandar Lampung. Luas wilayah sekitar 75 hektar, yang terdiri dari 28 RT.

Kelurahan Perumnas Way Kandis berdiri sejak tahun 2002, merupakan pemecahan dari Kelurahan Way Kandis, dan baru berjalan pada tahun 2004. Jumlah penduduk sebanyak 7.312 jiwa, terdiri dari 3.648 laki-laki dan 3.664 perempuan, dengan jumlah rumah sebanyak 1.527 rumah.

\section{Kepadatan Jentik}

Hasil penelitian (Tabel 1) mendapatkan bahwa dari 94 rumah yang diperiksa, sebanyak 30 rumah ditemukan jentik Ae, aegypti $(\mathrm{HI}=31,9 \%)$. Hasil ini lebih besar, dibandingkan pemeriksaan jentik pada tahun 2014 dan 2015, yaitu sebesar $17 \%$ dan $11 \%$.

Sebanyak 216 kontainer diperiksa, dan ditemukan jentik Ae. aegypti pada 56 kontainer $(\mathrm{CI}=44,9 \%)$. Berdasarkan hasil pemeriksaan kontainer, ditemukan lebih banyak jentik $A e$. aegypti (44,4\%), dibandingkan jentik Aedes albopictus $(2,31 \%)$. Sedangkan nilai $B I$ sebesar $59,6 \%$.

Tabel 1. Indeks Kepadatan Jentik Ae. aegypti

\begin{tabular}{clc}
\hline No & \multicolumn{1}{c}{ Parameter } & Nilai \\
\hline 1 & House Index $(H I$ & $31,9 \%$ \\
2 & Container Index (CI) & $44,4 \%$ \\
3 & Breteau Index (BI). & $59,6 \%$ \\
\hline
\end{tabular}

\section{Tempat perindukan}

Pengamatan tempat perindukan nyamuk Ae. aegypti meliputi jenis kontainer, bahan, letak, warna, suhu ruangan, kelembaban udara dan intensitas cahaya. Berdasarkan pengamatan (Tabel 2), jenis kontainer yang banyak ditemukan jentik Ae. Aegypti adalah bak mandi/wc $(15,7 \%)$, sedangkan sisanya ember 
$(9,7 \%)$ dan tempat penampungan air buangan dispenser $(0,5 \%)$.

Berdasarkan bahan kontainer, jentik pupa Ae aegypti ditemukan pada kontainer dari bahan plastik $(14,8 \%)$, semen $(6,0 \%)$, fiber $(3,2 \%)$, dan keramik $(1,9 \%)$.

Tabel 2. Tempat Perindukan Nyamuk

\begin{tabular}{|c|c|c|c|c|}
\hline \multirow{2}{*}{ Variabel } & \multicolumn{2}{|c|}{ Positif Ae. aegypti } & \multicolumn{2}{|c|}{ Negatif $A e$. aegypt } \\
\hline & $\mathrm{n}$ & $\%$ & $\mathrm{n}$ & $\%$ \\
\hline \multicolumn{5}{|l|}{ Jenis Kontainer } \\
\hline Bak mandi/wc & 34 & 15,7 & 83 & 38,4 \\
\hline Ember & 21 & 9,7 & 52 & 24,1 \\
\hline Tempat minum burung & 0 & 0,0 & 4 & 1,9 \\
\hline Vas bunga/pot & 0 & 0,0 & 3 & 1,4 \\
\hline Tempat penampungan air buangan dispenser & 1 & 0,5 & 17 & 7,9 \\
\hline Pelepah daun & 0 & 0,0 & 1 & 0,5 \\
\hline \multicolumn{5}{|l|}{ Bahan Kontainer } \\
\hline Semen & 13 & 6,0 & 32 & 14,8 \\
\hline Plastik & 32 & 14,8 & 92 & 42,6 \\
\hline Fiber & 7 & 3,2 & 30 & 13,9 \\
\hline Keramik & 4 & 1,9 & 5 & 2,3 \\
\hline Daun & 0 & 0,0 & 1 & 0,5 \\
\hline \multicolumn{5}{|l|}{ Letak Kontainer } \\
\hline Dalam Rumah & 56 & 25,9 & 155 & 71,8 \\
\hline Luar Rumah & 0 & 0,0 & 5 & 2,3 \\
\hline \multicolumn{5}{|l|}{ Warna Kontainer } \\
\hline Gelap & 38 & 17,6 & 63 & 29,2 \\
\hline Terang & 18 & 8,3 & 97 & 44,9 \\
\hline
\end{tabular}

Hasil pengukuran rata-rata suhu ruangan terdapat kontainer positif jentik Ae. aegypti sebesar $29,54^{\circ} \mathrm{C}$. Sedangkan kelembaban udara terdapat kontainer positif jentik Ae. aegypti yaitu $76,29 \%$. Pengukuran intensitas cahaya menggunakan Lux Meter. Rata-rata intensitas cahaya ruangan terdapat kontainer positif jentik Ae. aegypti sebesar 46,50 lux (Tabel 3).

Tabel 3. Kualitas Fisik Udara

\begin{tabular}{lll}
\hline No & \multicolumn{1}{c}{ Parameter } & Nilai \\
\hline 1 & Suhu $\left({ }^{0} \mathrm{C}\right)$ & 29,54 \\
2 & Kelembaban (\%) & 76,29 \\
3 & Intensitas cahaya (Lux) & 46,50 \\
\hline
\end{tabular}

\section{Tempat Peristirahatan Nyamuk}

Pengamatan tempat peristirahatan nyamuk meliputi tempat, suhu ruangan, kelembaban udara dan intensitas cahaya. Hasil penelitian mendapatkan bahwa dari 94 rumah yang diamati terdapat 13 rumah yang positif terdapat nyamuk Ae. Aegypti (Tabel 4), dan keseluruhannya terdapat di dalam rumah $(11,8 \%)$.
Tabel 2 juga menunjukkan bahwa kontainer di dalam rumah $(25,9 \%)$, dan berwarna gelap $(17,6 \%)$ lebih banyak terdapat jentik Ae. aegypti 


\section{PEMBAHASAN}

\section{Tempat perindukan Nyamuk}

\section{a. Jenis Kontainer}

Hasil penelitian mendapatkan bahwa kontainer yang paling banyak ditemukan jentik Ae aegypti adalah bak mandi/wc $(15,7 \%)$, dan sisanya adalah ember $(9,7 \%)$ dan tempat penampungan air buangan dispenser $(0,5 \%)$. Hasil penelitian sejalan dengan penelitian Yudhastuti, R dan Vidiyani, A (2005) di Kelurahan Wonokusumo Kota Surabaya, bahwa ada hubungan yang bermakna antara jenis kontainer dengan keberadaan jentik nyamuk $A e$. Aegypti. Jenis kontainer ditemukan jentik Ae. aegypti adalah bak mandi. Hasil yang sama juga disampaikan oleh Wisfer, dkk (2014), bahwa jenis TPA yang paling banyak ditemukan larva Ae aegvpti adalah bak mandi.

Bak mandi menjadi TPA yang paling banyak ditemukan jentik Ae. aegypti karena hampir setiap rumah responden memiliki bak mandi. Kebiasaan masyarakat untuk selalu mengisi air pada bak mandi memungkinkan air tinggal dalam waktu yang lama. Selain itu, kebiasaan masyarakat dalam membersihkan bak mandi ketika sudah terlihat kotor, dan hanya membuang airnya tanpa menyikat permukaan dinding bak. Sehingga telur nyamuk untuk tetap tinggal.

Sebaiknya pengurasan bak mandi/wc dilakukan minimal satu minggu sekali dan menyikat dinding bak. Pemberian bubuk abate disarankan pada bak/TPA berukuran besar. Sedangkan pada TPA di luar rumah, dapat memelihara ikan pemakan jentik seperti ikan cupang.

\section{b. Bahan Kontainer}

Dari hasil penelitian diperoleh data bahwa jentik Ae. aegypti paling banyak ditemukan pada kontainer yang terbuat dari plastik $(14,8 \%)$, sedangkan sisanya semen $(6,0 \%)$, fiber $(3,2 \%)$ dan keramik $(1,9 \%)$. Berbeda dengan penelitian yang dilakukan oleh $\mathrm{H}$. Hasyimi dan Soekirno, M (2004) di Kelurahan Papanggo Kecamatan Tanjung Priok Jakarta Utara bahwa yang paling banyak ditemukan jentik/pupa Ae aegypti adalah TPA terbuat dari bahan logam (drum).

Namun, penelitian ini sejalan dengan Pramestuti, N dan Farida T, Ulfah (2013) di Kabupaten Banjarnegara, bahwa bahan dasar tempal perindukan Ae. aegypti yang ditemukan sebagian besar terbuat dari plastik dan semen.
Bahan dasar kontainer berpengaruh pada ketersediaan makanan bagi larva, karena mikroorganisme akan menempel pada dinding kontainer. Oleh karena itu, sebaiknya pada saat melakukan pengurasan harus dilakukan pembersihan dengan cara menyikat pada bagian dinding kontainer, sehingga tidak menjadi tersedianya tempat makanan bagi jentik.

\section{c. Letak Kontainer}

Berdasarkan hasil observasi diketahui bahwa jentik Ae. aegypti menyukai kontainer yang berada di dalam rumah $(25,9 \%)$. Tidak ditemukan jentik Ae. aegypti di kontainer yang berada di luar rumah.

Hasil penelitian ini sejalan dengan Yudhastuti, R dan Vidiyani, A (2005) yang menyampaikan bahwa jentik Ae. aegypti ditemukan pada TPA di dalam rumah. Penelitian lain yang dikemukakan oleh Agus, Made, dkk (2008) juga menyatakan bahwa nyamuk $A e$ aegypti lebih suka dengan kontainer yang berada didalam rumah.

Letak kontainer yang berada di dalam rumah berpeluang lebih besar untuk terdapat jentik Ae. aegypti, hal ini dipengaruhi oleh kondisi rumah yang gelap karena kurangnya cahaya matahari. Kurangnya sinar matahari akan menurunkan suhu dan meningkatkan kelembaban di dalam rumah. Kondisi gelap dan lembab merukan suasana lingkungan yang disukai nyamuk $A e$. Aegypti.

\section{d. Warna Kontainer}

Hasil penclitian menunjukkan bahwa kontainer dengan warna gelap lebih banyak ditemukan jentik Ae. aegypti $(17,6 \%)$ dibandingkan yang berwarna terang $(8,3 \%)$.

Menurut Vezzani, dkk di Buenos Aires, Argentina yang dikutip oleh Pramestuti, $\mathrm{N}$ dan Farida T, Ulfah (2013), wadah dengan bahan dasar plastik yang berwarna hitam mengandung lebih banyak jentik Ae. aegypti $(82,1 \%)$. Penelitian ini sejalan dengan penelitian yang dilakukan oleh Budiyanto, A (2012), bahwa warna kontainer yang lebih gelap lebih disukai nyamuk sebagai tempat perindukan.

Warna gelap dapat memberikan rasa aman dan tenang bagi nyamuk Ae aegypti pada saat bertelur, sehingga telur yang diletakkan dalam TPA lebih banyak. Pada beberapa kontainer berwarna terang (seperti warna hijau muda) yang ditemukan telur dan jentik, kondisinya jarang dibersihkan sehingga permukaan kontainer ditumbuhi lumut dan menjadi gelap. 
Oleh karena itu, sebaiknya dalam pemilihan kontainer digunakan yang berwarna terang, diberi penutup, dan dibersihkan secara rutin minimal seminggu sekali.

\section{e. Suhu Ruangan}

Suhu udara merupakan salah satu faktor lingkungan yang mempengaruhi kehidupan nyamuk. Nyamuk Ae. aegypti akan meletakkan telurnya pada temperatur udara sekitar $20-30^{\circ} \mathrm{C}$. Telur yang diletakkan dalam air akan menetas dalam 1-3 hari pada suhu $30^{\circ} \mathrm{C}$. Pada suhu udara $16^{\circ} \mathrm{C}$, dibutuhkan waktu selama 7 hari. Nyamuk dapat hidup pada suhu rendah tetapi proses metabolismenya menurun atau bahkan berhenti apabila suhu turun sampai dibawah suhu kritis.

Dari hasil penelitian diketahui bahwa ratarata suhu ruangan terdapat kontainer sebesar $29,60^{\circ} \mathrm{C}$, sedangkan rata-rata suhu ruangan terdapat kontainer positif jentik Ae. aegypti sebesar $29,54^{\circ} \mathrm{C}$. Sedangkan rata-rata suhu ruangan terdapat kontainer negatif jentik $A e$. aegypti sebesar $29,63^{\circ} \mathrm{C}$. Tidak terdapat perbedaan yang signifikan antara rata-rata suhu ruangan kontainer positif Ae. aegypti dengan kontainer negatif.

Penelitian ini sesuai dengan Yudhastuti, R dan Vidiyani, A (2005), bahwa tidak ada hubungan yang bermakna antara suhu udara dengan keberadaan jentik nyamuk Ae. aegypti.

Walaupun tidak berpengaruh, masyarakat harus tetap waspada karena dalam suhu udara yang optimal $\left(20-30^{\circ} \mathrm{C}\right)$, nyamuk Ae. aegypti akan lebih cepat menetas. Sebaiknya masyarakat harus selalu mengelola TPA dengan baik. Meningkatkan jumlah cahaya matahari yang masuk ke dalam rumah, misalnya memasang genteng kaca atau glass block, merupakan upaya untuk menungkatkan suhu ruangan sekaligus menurunkan kelembaban udara.

\section{f. Kelembaban Udara}

Hasil pengukuran kelembaban udara di ruangan terdapat kontainer positif jentik $A e$. aegypti sebesar $76,29 \%$, pada ruangan dengan kontainer negatif jentik sebesar $75,88 \%$. Sedangkan rata-rata kelembaban udara dalam rumah sebesar 76,95\%. Hasil pengukuran menunjukkan perbedaan nilai kelembaban antara ruangan dengan kontainer positif dan negatif jentik Ae. Aegypti, sekitar 1\%.

Penelitian ini sesuai dengan penelitian Yudhastuti, R dan Vidiyani, A (2005) yang menyebutkan bahwa kepadatan jentik berhubungan dengan letak kontainer, kelembaban udara, dan jenis kontainer.

Dalam kehidupan nyamuk, kelembaban udara mempengaruhi kebiasaan meletakkan telurnya. Menurut Sallata, Meilson H.E (2014) kelembaban udara optimum berkisar antara $60 \%-80 \%$. Kelembaban yang tinggi akan mempercepat proses pertumbuhan nyyamuk. Oleh karena itu, perlu memperhatikan kelembaban dalam rumah. Meningkatkan suhu udara serta ventilasi yang baik, merupakan upaya yang dapat dilakukan untuk menurunkan kelembaban udara dalam rumah.

\section{g. Intensitas Cahaya}

Pengukuran intensitas cahaya ruangan terdapat terdapat kontainer positif jentik $A e$. aegypti sebesar 46,50 lux, sedangkan yang negatif sebesar 47,59 lux. Terlihat bahwa kontainer terdapat jentik Ae. Aegypti berada pada ruangan yang lebih gelap.

TPA di ruangan yang gelap lebih disukai nyamuk sebagai tempat perindukan. Lingkungan yang gelap akan melindungi nyamuk dari hewan predator. Selain itu, larva nyamuk Ae. aegypti dapat bertahan lebih baik di ruangan yang gelap. Menurut Anton Sitio, (2008), jentik Ae aegypti lebih banyak ditemukan dalam bejana di ruangan yang gelap, dibandingkan ruangan yang terang.

\section{Tempat Peristirahatan Nyamuk \\ a. Letak atau Tempat}

Berdasarkan hasil pemeriksaan 94 rumah, terdapat 13 rumah yang terdapat nyamuk $A e$. Aegypti, dan seluruhnya ditemukan di dalam rumah $(11,8 \%)$. Penelitian ini sejalan dengan Anton Sitio (2008) yang menyatakan bahwa nyamuk Ae. Aegypti lebih suka beristirahat di dalam rumah. Biasanya berada pada pakaian bekas pakai yang digantung.

Setelah mengisap darah, nyamuk akan beristirahat pada tempat yang gelap dan lembab, berdekatan dengan tempat perindukan sambil menunggu proses pematangan telurnya (Kemenkes RI, 2011).

Ae. aegypti suka beristirahat di dalam rumah pada benda-benda yang bergantung seperti baju dan korden. Nyamuk ini jarang ditemukan di luar rumah, di tumbuhan atau di tempat terlindung lainnya (WHO, 2002). Oleh karena itu, sebaiknya perlu menghilangkan kebiasaan menggantung pakaian bekas pakai, serta 
memasang kawat kasa pada jendela dan lubang ventilasi.

\section{b. Suhu Ruangan}

Hasil pengukuran suhu ruangan pada rumah ditemukan nyamuk Ae. aegypti sebesar $29,46^{\circ} \mathrm{C}$, sedangkan rumah tidak ditemukan nyamuk sebesar $29,65^{\circ} \mathrm{C}$. Tidak terdapat perbedaan signifikan diantara keduanya.

Suhu udara merupakan salah satu faktor lingkungan yang mempengaruhi kehidupan $A e$. aegypti. Nyamuk dapat hidup pada suhu rendah tetapi proses metabolismenya menurun, bahkan berhenti. Rata-rata suhu optimum untuk pertumbuhan nyamuk adalah $25-27^{\circ} \mathrm{C}$, dan akan terhenti sama sekali pada suhu kurang dari $10^{\circ} \mathrm{C}$ atau lebih dari $40^{\circ} \mathrm{C}$. Oleh karena itu, perlu meningkatkan suhu dalam rumah dengan meningkatkan masuknya cahaya matahari, serta menjamin terjadinya sirkulasi udara yang baik. Meningkatkan pemcahayaan dalam ruangan, secara langsung akan meningkatnya suhu udara, dan menurunkan kelembaban uadara.

\section{c. Kelembaban Udara}

Hasil pengukuran kelembaban udara di ruangan ditemukan nyamuk Ae. aegypti adalah $76 \%$, sedangkan yang tidak ditemukan nyamuk Ae. aegypti sebesar $75 \%$.

Kelembaban udara optimum bagi kelangsungan hidup nyamuk adalah sekitar 60 $80 \%$. Kelembaban yang tinggi akan mempercepat proses pertumbuhan nyamuk. Oleh karena itu, perlu melakukan pengelolaan kelembaban udara dalam rumah, dengan cara meningkatkan intensitas pencahayaan alami, serta menjamin sirkulasi udara yang baik.

\section{d. Intensitas Cahaya}

Hasil pengukuran intensitas pencahayaan di ruangan ditemukan nyamuk $A e$ aegypti adalah 62,30 lux, sedangkan yang tidak ditemukan nyamuk Ae. aegypti sebesar 66,77 lux. Terlihat bahwa nyamuk ditemukan di ruangan yang lebih gelap.

Cahaya merupakan faktor utama yang mempcngaruhi nyamuk dalam memilih tempat beristirahat. Nyamuk lebih suka pada ruangan dengan intensitas pencahayaan rendah, dan kelembaban tinggi. Kondisi ruangan yang gelap akan melindungi nyamuk dari hewan predator. Menurut (nton Sitio (2008), intensitas pencahayaan merupakan faktor terbesar yang mempengaruhi aktivitas terbang nyamuk, yaitu kurang dari 215 lux.

\section{KESIMPULAN}

Bionomik nyamuk Ae. aegypti dalam memilih tempat perindukan di lokasi penelitian adalah kontainer jenis bak mandi/wc, berbahan dasar plastik, dan berwarna gelap. Nyamuk Ae. aegypti lebih suka bertelur pada kontainer yang berada di dalam rumah, dengan rata-rata suhu ruangan $29,54^{\circ} \mathrm{C}$, kelembaban udara $76,29 \%$ dan intensitas pencahayaan 46,50 lux.

Sedangkan dalam memilih tempat beristirahat, nyamuk Ae. aegypti lebih suka di dalam rumah dengan rata-rata suhu ruangan $29,46^{\circ} \mathrm{C}$, kelembaban udara $76 \%$, dan intensitas cahaya 62,30 lux.

\section{DAFTAR PUSTAKA}

Agus, Made, dkk, 2008. Preferensi Jentik Aedes aegypti terhadap Jenis Kontainer Di Kota Palu. Jurnal Vektor Penyakit, Vol.1, No. 2, 2008: 9-14.

Budiyanto, Anif. 2012. Perbedaan Warna Kontainer Berkaitan Dengan Keberadaan Jentik Aedes Aegypti Di Sekolah Dasar. jurnal Biotek Medisiana Indonesia, Vol.1.2.2012: 65-71, Sumatera Selatan.

Kemenkes RI. 2005. Pencegahan dan Pemberantasan Demam Berdarah Dengue di Indonesia. Jakarta: Ditjen P2M

Dinas Kesehatan Kota Bandar Lampung. 2010. Profil Dinas Kesehatan 2010. Kota Bandar Lampung. Lampung.

Dinas Kesehatan Kota Bandar Lampung.Profil Dinas Kesehatan 2011. Kota Bandar Lampung. Lampung. 2012. Profil Dinas Kesehatan 2012. Kota Bandar Lampung. Lampung.

Dinas Kesehatan Kota Bandar Lampung.Profil Dinas Kesehatan 2013. Kota Bandar Lampung. Lampung.

Dinas Kesehatan Kota Bandar Lampung.Profil Dinas Kesehatan 2014. Kota Bandar Lampung. Lampung.

Hadinegoro, Sri Rezeki, dkk. 2002. Demam Berdarah Dengue. Jakarta: Penerbit FKUI

Hasyim, H dan Soekirno, M. 2004. Pengamatan Tempat Perindukan Aedes aegypti Pada Tempat Penampungan Air Rumah Tangga Pada Masyarakat Pengguna Air Olahan. Jurnal Ekologi Kesehatan. Vol.3, No.1, April 2004: 37-42, Jakarta Utara. 
Kemenkes RI. 2005. Pencegahan dan Pemberantasan Demam Berdarah Dengue di Indonesia, Jakarta: Ditjen P2M

Kemenkes RI. 2011. Modul Pengendalian Demam Berdarah Dengue. Jakarta: Direktorat jendral P2PL.

Notoatmodjo, Soekidjo, 2005. Metode Penelitian Kesehatan. Jakarta: Rineka Cipta.

Pramestuti, N dan Farida T, Ulfah.2013. Jenis Dan Bahan Dasar Tempat Perkembangbiakan Vektor Demam Berdarah Dengue (DBD) Di Kabupaten Banjarnegara. Jurnal BALABA, Vol.9, No. 01, Juni 2013: 11-16, Banjarnegara.

Safar, Rosdiana. 2010. Parasitologi Kedokteran. Bandung: CV. Yrama Widya.

Sallata, Meilson H.E,dkk. 2014. Hubungan karakteristik Lingkungan Fisisk Dan Kimia Dengan Keberadaan Larva Aedes aegypti Di Wilayah Endemis DBD Kota Makassar. Jurnal Kesehatan Lingkungan, Fakultas Kesehatan Masyarakat, Universitas Hasanuddin, Makassar.

Sitio, Anton. 2008. Hubungan Perilaku Tentang Pemberantasan Sarang Nyamuk dan Kebiasaan Keluarga Dengan Kejadian Demam Berdarah Dengue Di Kecamatan
Medan Perjuangan Kota Medan. Tesis Magister, Universitas Diponegoro, Semarang.

WHO (World Health Organization). 2002. Pencegahan \& Pengendalian Dengue \& Demam Berdarah. Jakarta: Buku Kedokteran EGC.

Widoyono. 2008. Penyakit Tropis Epidemiologi, Penularan, Pencegahan \& Pemberantasannya. Jakarta: Penerbit Erlangga.

Wisfer, dkk. 2014. Hubungan Jumlah Penghuni Tempat Pcnampungan Air Kcluarga Dengan Keberadaan Larva Aedes Aegypti Di Wilayah Endemis DBD Di Kota Makassar. Jurnal Kesehatan Lingkungan, Fakultas Kesehatan Masyarakat, Universitas Hasanuddin, Makassar.

Yudhastuti, R dan Vidiyani, A. 2005. Hubungan Kondisi Lingkungan, Kontainer, dan Perilaku Masyarakat Dengan Keberadaan Jentik Nyamuk Aedes aegypti Di Daerah Endemis Demam Berdarah Dengue Surabaya. Jurnal Kesehatan Lingkungan, Vol.1, No. 2, Januari 2005, Surabaya.

Zulkoni, Akhsin. 2011. Parasitologi. Bantul, Yogyakarta: Nuha Medika 